\title{
Phylogenetic Position of Cryothecomonas Inferred from Nuclear-Encoded Small Subunit Ribosomal RNA
}

\author{
Stefanie Kühna, Martin Lange ${ }^{b}$, and Linda K. Medlin ${ }^{b, 1}$ \\ aUniversity of Bremen, Marine Botany (FB 2), Leobener Str./NW2, 28357 Bremen, Germany \\ ${ }^{b}$ Alfred Wegener Institute for Polar and Marine Research, Postfach 120161, Columbusstrasse, 27515 Bremerhaven, \\ Germany
}

Submitted August 22, 2000; Accepted October 31, 2000

Monitoring Editor: Robert A. Andersen

The systematic position of the genus Cryothecomonas has been determined from an analysis of the nuclear-encoded small subunit ribosomal RNA gene of Cryothecomonas longipes and two strains of Cryothecomonas aestivalis. Our phylogenetic trees inferred from maximum likelihood, distance and maximum parsimony methods robustly show that the genus Cryothecomonas clusters within the phylum Cercozoa, and is related to the sarcomonad flagellate Heteromita globosa. Morphological data supporting the taxonomic placement of Cryothecomonas near the sarcomonad flagellates has been compiled from the literature. The high number of nucleotide substitutions found between two morphologically indistinguishable strains of Cryothecomonas aestivalis suggests the possibility of cryptic species within Cryothecomonas aestivalis.

\section{Introduction}

The enormous diversity of small free-living heterotrophic flagellates (Patterson and Larsen 1991) has in recent years become a focus of attention of ecologists and taxonomists. The importance of heterotrophic nanoflagellates in marine pelagic food webs as major consumers of bacteria and picophytoplankton has been widely acknowledged. Additionally, host specific parasitoid nano-flagellates, such as Cryothecomonas and Pirsonia, can cause great mortality among phytoplankton populations (Drebes et al. 1996; Kühn et al. 1996; Tillmann et al. 1999). The ecological importance of flagellates has made particular demands on systematists. Some

\footnotetext{
${ }^{1}$ Corresponding author;

fax 4947148311425

e-mail Imedlin@awi-bremerhaven.de
}

groups are relatively well-defined and are easily identified by diagnostic features. Electron microscopy has proved a powerful tool to reveal the ultrastructure of characteristic organellar appearances. Although flagellates can be distinguished by their structural properties, their taxonomic position often remains uncertain (e.g. Patterson and Zölffel 1991). Ribosomal RNA sequence comparisons have been proven to be a useful tool in molecular eukaryote and prokaryote evolution because this technique offers a measure of evolutionary relatedness that is independent of morphology (B hattacharya et al. 1995; Sogin et al. 1989; Van De Peer and De Wachter 1997; Woese 1987). Although the number of available ribosomal RNA sequences for molecular evolutionary analysis has grown continuously during the last two decades, only a tiny proportion of the great 
diversity of protists has been subjected to molecular genetic analysis (Cavalier-Smith 1998a; Schlegel 1991). Ribosomal RNA sequencing has led to fundamental revisions of protist taxonomy. It has been shown, for example, that lobose amoebae, such as Hartmannella and Acanthamoeba are not closely related to euglyphid filose amoebae (B hattacharya et al. 1995). These discoveries have led to the reclassification of the Cercozoa (syn. Rhizopoda Von Siebold 1845). In recent taxonomic treatments the modified phylum Cercozoa consists of taxa belonging to the subphyla Reticulofilosa, Monadofilosa and Phytomyxa (Cavalier-Smith 1996/97; 1998a; 2000).

Six species of the heterotrophic nanoflagellate Cryothecomonas have been described so far. Cryothecomonas appears to be a ubiquitous flagellate that occurs in polar and temperate waters tolerating salinity from 0.0 to $34 \mathrm{psu}$ and with cell densities up to $2.6 \times 10^{4}$ cells $\left.\right|^{-1}$ (Ikävalko and Thomsen 1997). Cryothecomonas was first decribed by Thomsen et al. (1991) based on three species from Danish waters (C. inermis, C. scybalophora, $C$. vesiculata) and C. armigera from the Weddell Sea, Antarctica. Recently two new species, Cryothecomonas longipes and Cryothecomonas aestivalis (strain 1 in this study) were described from the North Sea (Drebes et al. 1996; Schnepf and Kühn 2000). In this study we report the occurrence of another $C$. aestivalis strain (strain 2). Whereas some species (C. armigera and $C$. inermis) ingest nanoplanktonic algae $(2-4.5 \mu \mathrm{m})$, others feed on diatoms much larger than themselves by gradually phagocytizing host protoplasm, either by attaching to the outside of the frustule of the host diatom (e.g. C. longipes) or by invading the frustule (e.g. C. aestivalis strains 1 and 2).

Since its first description, the taxonomic position of Cryothecomonas has been a matter of discussion. Patterson and Zölffel (1991) hypothesized Cryothecomonas to be related to cercomonad amoeboflagellates. Cavalier-Smith (1993) erected the new order Cryomonadida with the sole family Cryothecomonadidae and placed it within the phylum Neomonada, Class Thecomonadea (CavalierSmith 1996/97). He pointed out that the theca of Cryothecomonas is probably not homologous to that of Apusomonas (Cavalier-Smith 1998b). Recently Cryothecomonas was transferred from the Thecomonadea into the Sarcomonadea without supporting morphological reasons (Cavalier-Smith 2000). Unfortunately, Cryothecomonas had not been analysed with molecular evolutionary methods. We have now sequenced the small subunit ribosomal RNA gene (SSU rRNA) from Cryothecomonas longipes and two strains of Cryothecomonas aestivalis and compared these sequences to SSU rRNAs from diverse eukaryotes. Our analyses confirm the current systematic position of Cryothecomonas as a sarcomonad flagellate.

\section{Results}

\section{Phylogenetic Analysis}

SSU rRNA sequences were determined for $C$ ryothecomonas longipes and two strains of Cryothecomonas aestivalis and deposited in Genbank. The SSU rRNA sequences of Cryothecomonas longipes, Cryothecomonas aestivalis strain 1 and strain 2 are 1819, 1815 and 1817 nucleotides in length respectively. In contrast to morphological similarity between Cryothecomonas aestivalis strains 1 and 2, both strains differ from each other by 8 nucleotide substitutions in their SSU rRNA sequences. The absolute number of nucleotide differences separating these strains is comparable to species differences between the bipolar haptophytes Phaeocystis antarctica and Phaeocystis pouchetii (6-10) (Medlin et al. 1994), within species of the diatom Skeletonema (11) (Medlin et al. 1991) and of the protozoan Tetrahymena (0-33) (Sogin et al. 1986). Cryothecomonas longipes is separated by 68 and 74 base substitutions from $\mathrm{Cryothecomonas}$ aestivalis strain 1 and Cryothecomonas aestivalis strain 2 respectively.

We have used two SSU rRNA data sets for the phylogenetic analyses. The large data set with representatives from all major eukaryotic lineages was used to infer the phylogenetic position of Cryothecomonas. The small data set contained all available SSU rRNA sequences from taxa belonging to the phylum Cercozoa. This data set was used to infer the position of Cryothecomonas within the Cercozoa.

The phylognetic position of Cryothecomonas as determined from a maximum likelihood analysis is shown in Figure 1 for the large data set and in Figure 2 for the small one. Cryothecomonas forms a monophyletic group within the phylum Cercozoa with $100 \%$ bootstrap support in both maximum parsimony and neighbor joining distance analysis (Figure 1). The branch leading to the Cercozoa is supported by high bootstrap values in the maximum parsimony and neighbor joining distance analysis, but Plasmodiophora brassicae (Phytomyxea) recently classified as belonging to the Cercozoa (Cavalier-Smith 1996/1997) is not included in this clade (Fig. 1). The sarcomonad flagellate Heteromita globosa appears as a sister taxon to Cryothecomonas in both maxi- 


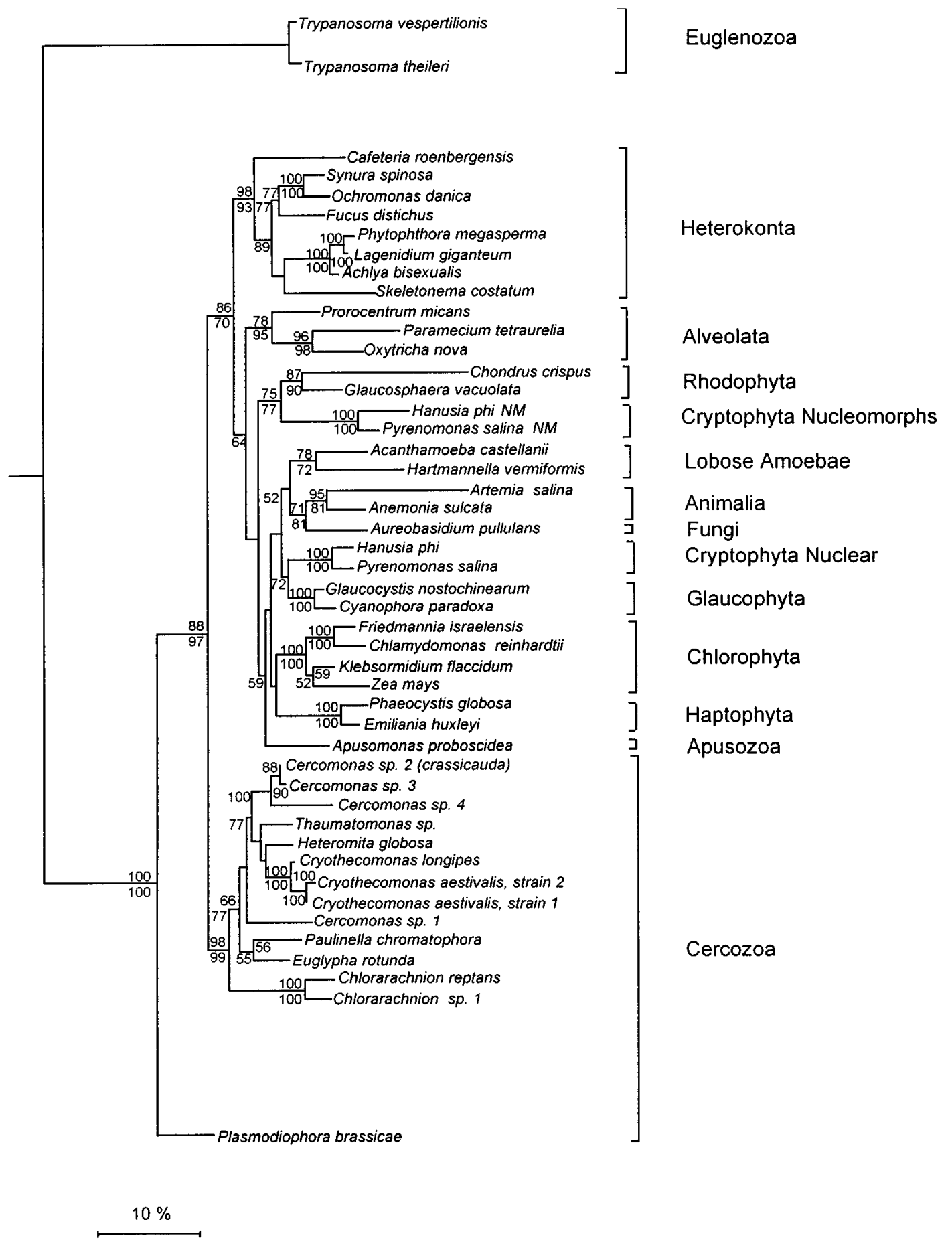

Figure 1. SSU-rRNA phylogeny of 47 eukaryotes based on sequence comparisons inferred with the maximum likelihood method using 1,546 unambiguously aligned nucleotides. The bootstrap values (500 replications) above the internal nodes are inferred from a maximum parsimony analysis, whereas the bootstrap values (500 replications) below the internal nodes are inferred using the neighbor-joining method. Only bootstrap values greater than $50 \%$ are reported. The scale below the tree indicates the branch length corresponding to ten changes per $100 \mathrm{nu}$ cleotide positions. 


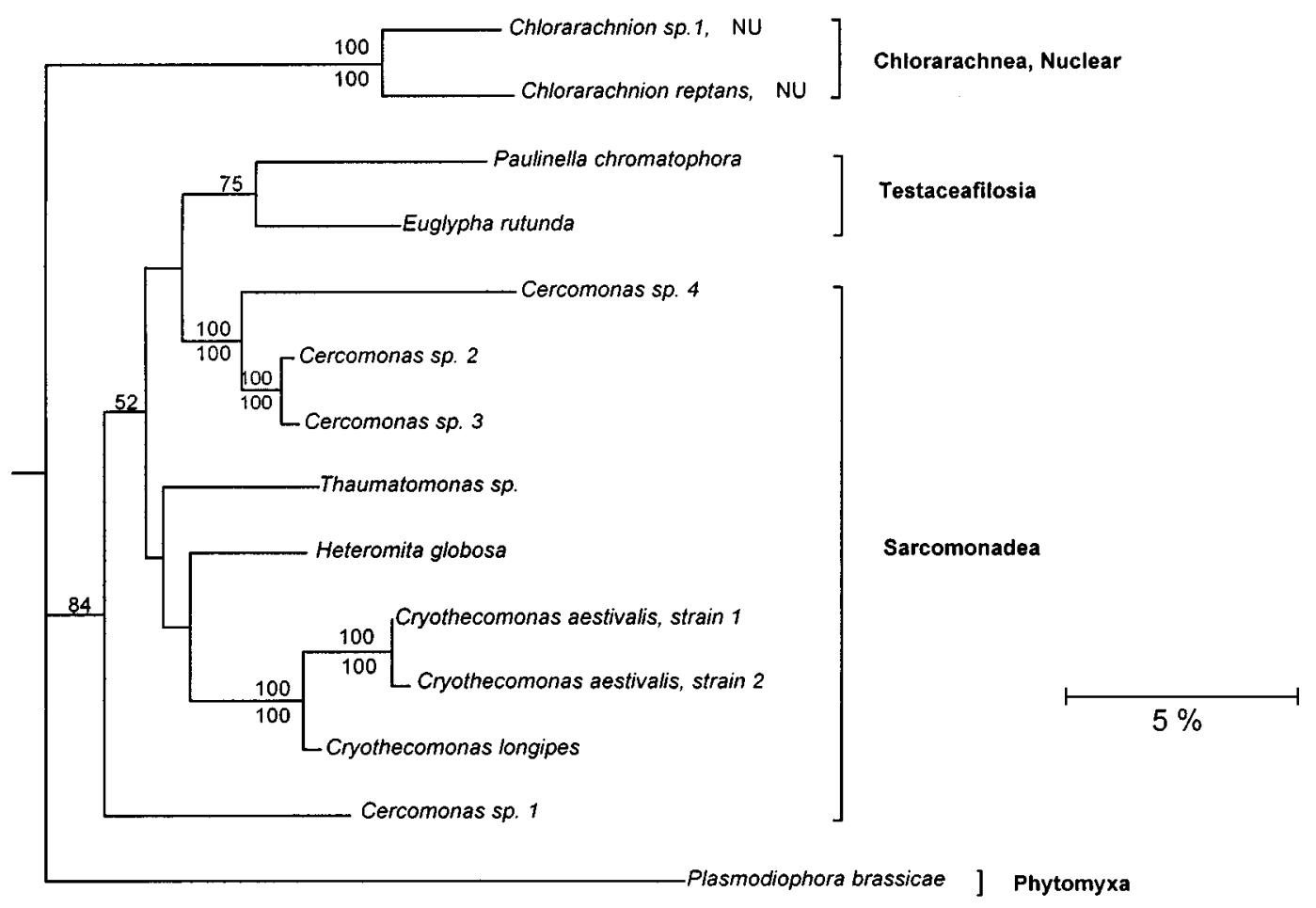

Figure 2. Eukaryotic phylogeny based on SSU rRNA sequence comparisons inferred with the maximum likelihood method using 1,559 unambiguously aligned nucleotides. The bootstrap values (500 replications) above the internal nodes are inferred from a maximum parsimony analysis, whereas the bootstrap values ( 500 replications) below the internal nodes are inferred using the neighbor-joining method. Only bootstrap values greater than $50 \%$ are reported. The scale below the tree indicates the branch length corresponding to five changes per 100 nucleotide positions.

mum likelihood trees; however, this relationship is not supported by bootstrap values (Figs. 1 and 2). Differences within the branching order between the maximum likelihood trees inferred from the large and small data set were observed (Figs. 1 and 2). In both trees Cercomonas appeared not as a monophyletic genus and Cercomonas sp. 1 was placed as the first divergence of the clade that contains the remaining Cercomonas species. However, in the maximum likelihood tree calculated from the small data set, Cercomonas sp. 1 was placed as a sister taxon to the Sarcomonadea/ Testaceafilosia clade (Fig. 2), whereas Cercomonas sp. 1 was placed between this clade in the maximum likelihood tree calculated from the large data set (Fig. 1). The Testaceafilosia appeared as a sister clade to the Sarcomonadea (Fig. 1), whereas the Testaceafilosia clade was placed as a sister to Cercomonas sp. 1-3 within the Sarcomonadea (Fig. 2). The tree inferred from the small data set utilised more unambiguously aligned nucleotide positions in the phylogenetic analyses and more likely reflects the correct evolutionary position of taxa in the Cercozoa (Fig. 2).

\section{Light Microscopy}

Because of the relatively high number of base substitutions found between Cryothecomonas aestivalis strain 1 and 2, we investigated both strains for morphological differences using light microscopy.

Morphologically, Cryothecomonas aestivalis strain 2 is very similar to $C$. aestivalis strain 1 Drebes, Kühn et Schnepf (Drebes et al. 1996). C. aestivalis strain 2 flagellates are oblong to oval, 5-6 $\mu \mathrm{m}$ wide (strain 1: 4-5 $\mu \mathrm{m}$ ) and 8.5-10 $\mu \mathrm{m}$ long (strain 1: 9-12 $\mu \mathrm{m}$ ), and have two heterodynamic flagella that are inserted apically. The anteriorly directed flagellum is 10-14 $\mu \mathrm{m}$ long (strain 1: up to $15 \mu \mathrm{m}$ ), and the posteriorly directed flagellum measures 16-23 $\mu \mathrm{m}$ (strain 1: up to $25 \mu \mathrm{m}$ ). Also, the life cycles of $C$. aestivalis strain 1 and strain 2 are identical: infective flagellates squeeze inside the host diatom frustule between the girdle bands and feed on the diatom protoplast by means of a pseudopodium. After the trophic phase flagellates divide several times and, depending on the size of the host cell, form up to 40 offspring. There are, however, slight differences in the host 
ranges: in contrast to $\mathrm{C}$. aestivalis strain $1, \mathrm{C}$. aestivalis strain 2 infects not only the chain-forming diatom Guinardia delicatula but also G. flaccida. In both parasitoid species, offspring develop after approximately 24 hours (at $15-20^{\circ} \mathrm{C}$ ) when feeding on G. delicatula. Whereas $C$. aestivalis strain 1 offspring leave the empty frustule immediately when digestion is finished, $C$. aestivalis strain 2 offspring remain inside the frustule of $G$. delicatula for up to several days but leave the frustule of $G$. flaccida immediately. Apparently, $G$. delicatula is not the ideal host for $C$. aestivalis strain 2 . Whereas $G$. delicatula cells are soon separated from sibling cells within the chain when infected with $C$. aestivalis strain 2, chains remain intact when infected with $C$. aestivalis strain 1.

\section{Discussion}

The genus Cryothecomonas is related to the phylum Cercozoa and not to the phylum Neomonada (e.g. Apusomonas proboscidea, Thecomonadea, see Cavalier-Smith and Chao 1995; 1996/97) as proposed earlier by Cavalier-Smith (1993, 1996/97, 1998b). Recently, Cryothecomoas was removed from the Thecomonadea and placed in the Sarcomonadea but the reasons for this transfer were not discussed (Cavalier-Smith 2000). Our SSU rRNA phylogenies confirm that Cryothecomonas is a sarcomonad flagellate. The morphological/ ultrastructural data corroborate this result because Cryothecomonas shares several characteristics with the sarcomonad flagellates Heteromita globosa, Thaumatomonas sp. and Cercomonas sp., but shows significant differences to Apusomonas proboscidea. Most characteristically, Apusomonas has an anterior proboscis with two emerging flagella that terminate in an acronema and a posteriorly located nucleus (Karpov and Zhukov 1986). In sarcomonads the nucleus is located anteriorly and an acronema is absent.

Sarcomonad flagellates, including Cryothecomonas, are colourless amoeboflagellates that feed by means of pseudopodia because they lack a discrete mouth. Pseudopodia emerge ventrally from a groove in Thaumatomonas and Cryothecomonas, whereas in Cercomonas and Heteromita, pseudopodia formation is not restricted to a particular area of the body. Two flagella are inserted apically or subapically at the anterior cell pole. They are retained but remain immobile during pseudopodial engulfment of food. The anterior basal bodies are directed forward, the posterior basal bodies at an angle of $90^{\circ}$ (Thaumatomonas: $30^{\circ}$ ). The glycocalyx is generally thick and distinct. Extrusomes are present in some species. The nucleus with a central dense nucleolus is located anteriorly. Mitochondrial cristae are tubular or vesicular. Food vacuoles are located in posterior region of the cell (Drebes et al. 1996; Karpov 1997; MacDonald et al. 1977; Mignot and Brugerolle 1975; Mylnikov 1986; Robertson 1928; Schnepf and Kühn 2000; Schuster and Pollak 1978; Shirkina 1987).

Heteromita, Thaumatomonas and Cryothecomonas have a spiral fiber or transitional helix in the transition zone of each flagellum (Drebes et al. 1996; Karpov 1997; Karpov and Fogin 1995; Schnepf and Kühn 2000; Thomsen et al. 1991), which is absent in Cercomonas (e.g. Karpov 1997).

From available morphological and molecular genetic data, we can confirm the current taxomonic placement of Cryothecomonas in the phylum Cercozoa, class Sarcomonadea (Cavalier-Smith 2000). Our phylogenetic analysis also shows that Cryothecomonas, euglyphid testate amoebae and sarcomonad flagellates shared a common evolutionary ancestor, whereas the Chlorarachniophyta (e.g. Chlorarachnion reptans) and the Phytomyxa (e.g. Plasmodiophora brassicae) diverged earlier. Euglypha rotunda and Paulinella chromatophora (Euglyphina) form a separate cluster within the Cercozoa (Figs. 1 and 2). This result is in agreement with the hypothesis by Cavalier-Smith (1996/1997) that euglyphid testate amoebae evolved from sarcomonad flagellates by the loss of flagella. The genus Cercomonas is polyphyletic (Figs. 1 and 2) as demonstrated in previous studies (Cavalier-Smith 1996/97; Cavalier-Smith and Chao 1996/1997; CavalierSmith 2000).

Our phylogenetic analysis indicates that $\mathrm{C}$. longipes diverged prior to the separation of both $C$. aestivalis strains. $C$. longipes has a broad host range and infects at least 14 diatom species (Schnepf and Kühn 2000). C. aestivalis strain 1 infects only Guinardia delicatula (Drebes et al. 1996), whereas C. aestivalis strain 2 infects two diatom species of the same genus (Guinardia delicatula and G. flaccida). Thus host-specific species represents the derived condition and evolution perfects the parasitoids so that they are host-specific.

In our analysis Plasmodiophora brassicae appears not to be closely related to the Cercozoa or to any other eukaryote sequence included in our alignment. This organism contains three large insertion sequences in its SSU rRNA gene consisting of 388, 383 and 442 nucleotides (Castlebury and Domier 1998), which have to be excluded from the phylogenetic analysis. In earlier SSU rRNA phylogenetic studies, Plasmodiophora brassicae formed the 
deepest branch in the Cercozoa clade (CavalierSmith 1996/97; Cavalier-Smith and Chao 1996/ 1997; Cavalier-Smith 2000). Other phylogenetic studies with rDNA sequences indicate that Plasmodiophora brassicae is a distinct group and not closely related to any other eukaryotes (Castlebury and Domier 1998; Ward and Adams 1998). Unfortunately, the last two studies did not include representatives of the Cercozoa in their phylogenetic analyses.

The unexpected high number of nucleotide differences (8) between two morphological indistinguishable strains of Cryothecomonas aestivalis isolated near Sylt and Heligoland suggest the possibility of cryptic species within Cryothecomonas aestivalis. Variation within SSU or LSU rRNA sequences of strains of a morphologically well-defined species has been reported for many species in the marine environment (Knowlton 1993; Medlin et al. 1995). Sequence data from the D1/D2 region of the $L S U$ rRNA, for example, revealed the existence of $46 \mathrm{sib}-$ ling species within the dinoflagellate Crypthecodinium cohnii and 25 sibling species within the protozoan Tetrahymena pyriformis (Beam et al. 1993, Preparata et al. 1992). Intraspecific sequence variation (up to 5 nucleotides) within the SSU rRNA of strains of Phaeocystis globosa (Lange 1997; Medlin et al. 1994) has been used together with differences in genome sizes within Phaeocystis globosa strains (Vaulot et al. 1994) to demonstrate the occurrence of cryptic species within the Phaeocystis globosa complex (Lange 1997; Medlin et al. 1995). The Cryothecomonas aestivalis strains could be separated by differences in their host specificity and by variation within their SSU rRNA sequences. The lack of any morphological differences between both strains can be explained by possible disparity between morphological and molecular rates of evolution. Similarities in body shape within marine phytoflagellate species is thought to reflect selection pressure and adaptation to the marine environment (Knowlton 1993; Medlin et al. 1995).

\section{Methods}

Cultures and DNA extraction: $C$. aestivalis strain 1 was isolated in Autumn 1994 from plankton samples collected in the Wadden Sea off List/Sylt (North Sea, German Bight), when infecting Guinardia delicatula (Drebes et al. 1996). Cryothecomonas aestivalis strain 2 was isolated in July 1999 from plankton samples collected at Heligoland (North Sea, German Bight), feeding inside $G$. delicatula and $G$. flaccida (Castracane) H. Peragallo. Flagellates were maintained in $F / 2$ medium (Guillard and Ryther 1962) with $\mathrm{G}$. delicatula as host at $15^{\circ} \mathrm{C}$ on a $16 / 8-\mathrm{h}$ light/dark cycle and 25-30 $\mu \mathrm{mol}$ photons $\mathrm{m}^{-2} \mathrm{~s}^{-1}$. Twice a week a few $\mu$ l of an infected culture was inoculated into a new host culture. Living cells were observed under the light microscope at room temperature. C. longipes was isolated at List/Sylt in September 1998 (Schnepf and Kühn 2000) and maintained with Thalassiosira rotula Meunier. Cultures were harvested when all diatoms were infected and effectively dead to prevent diatom DNA contamination and frozen immediately in liquid nitrogen until needed or used directly for DNA extraction. Total nucleic acids were obtained using a 3\% CTAB (hexadecyltrimethylammonium bromide) procedure (Doyle and Doyle 1990). Cultures of the protist strains used in this study are available from the authors upon request.

Amplification: Total nucleic acid preparations were used as templates for the amplification of SSU rRNA genes using conserved primers (Medlin et al. 1988). Each $100 \mu \mathrm{L} P C R$ reaction contained $100 \mathrm{ng}$ total nucleic acids, $1 \mathrm{mM}$ of each dATP, dGTP, dCTP and dTTP, $10 \mu \mathrm{M}$ of each primer, $10 \mu \mathrm{L}$ of $10 \times$ reaction buffer (100 mM Tris, (pH 8.4), 500 mM KCl, 20 $\mathrm{mM} \mathrm{MgCl} 2,0.1 \%$ gelatin) and 1.5 units Ampli-Taq DNA polymerase (PERKIN-ELMER, Foster City, CA). $P C R$ reactions were performed using a PerkinElmer-Cetus thermocycler with an initial denaturation step of $95^{\circ} \mathrm{C}$ for 6 min after which the Taq polymerase was added as the heating block cooled to $60^{\circ} \mathrm{C}$, followed by 29 cycles of $72^{\circ} \mathrm{C}$ for $4 \mathrm{~min}, 94^{\circ} \mathrm{C}$ for $2 \mathrm{~min}, 45^{\circ} \mathrm{C}$ for $2 \mathrm{~min}$, and a final extension step $72{ }^{\circ} \mathrm{C}$ for $9 \mathrm{~min}$. Ten $\mu \mathrm{L}$ of the amplification products were checked for correct length, purity and yield on ethidium bromide-stained $1.5 \%$ agarose gels (Sambrook et al. 1989) visualized by UV and photographed with Polaroid 667 film.

Sequence analysis: PCR products were prepared for sequencing using the $P C R$ purification kit from QIAGEN (Hilden, Germany) following the instructions of the manufacturer. Sequencing was performed using the Sequi-Therm-Cycle Sequencing kit from BIOZYM (Hess. Oldendorf, Germany) using up to $200 \mathrm{ng} P C R$ product per reaction and following the instructions of the manufacturer. Sequencing reactions were run on an automated Licor sequencer (MWG, Ebersberg, Germany). Sequence outputs were checked and manually corrected.

Phylogenetic analysis: Sequences were added to an alignment, which contained over 300 small subunit rRNA genes from eukaryotic organisms (data not shown), using maximum primary and secondary structural similarity with the Olsen sequence editor (Larsen et al. 1993) on a VAX 6520 computer. 
From this alignment a subset was selected consisting of 47 taxa, among which Trypanosoma theileri and Trypanosoma vespertilionis were selected as outgroup taxa (Fig. 1). A second subset consisting of 14 sequences was selected from the large data set to investigate the phylogenetic position of Cryothecomonas within the phylum Cercozoa using Plasmodiophora brassicae as outgroup (Fig. 2). Maximum likelihood, distance and parsimony analyses were performed using 1546 and 1559 unambiguously aligned nucleotides in the large and small data set respectively.

Maximum likelihood analysis: Maximum likelihood analysis was performed with the fastDNAml program (V1.0 Olsen et al. 1994). Global rearrangements of the full tree were performed and 44 branches (large data set) or 11 branches (small data set) were crossed. Taxon addition was performed randomly and a transition/transversion ratio $=2$ was used. With this method a total of 21,511 trees (large data set) or 1,716 trees (small data set) was examined, from which the tree with the highest likelihood value was selected (large data set, $\mathrm{Ln}$ likelihood $=$ -23822.09759), (small dataset, Ln likelihood = -7048.84161).

Distance analysis: A neighbor-joining bootstrap analysis (500 replicates) for both data sets was performed using the PHYLIP computer program (version 3.5, Felsenstein 1993). Dissimilarity values (Fitch and Margoliash 1967) based on pairwise comparisons of sequences, were transformed into distances using the Kimura-two-parameter model (Kimura 1980). Distance matrices were converted into trees using the neighbor-joining method (Felsenstein 1993) with jumbled taxon addition and the transition/transversion ratio $=2$.

Maximum parsimony analysis: A maximum parsimony bootstrap analysis (500 replicates) for both data sets was performed using the PAUP computer program (V3.1.1 Swofford 1993). Introduced gaps were treated as missing data; informative characters were treated as multistate unordered. Maximum parsimony trees were analysed with a heuristic search method with a tree-bisection-reconnection (TBR) branch swapping option with random taxon addition. SSU rRNA sequences used in this study (with EMBL/Genbank numbers) are as follows: (Acanthamoeba castellanii (Douglas) Page, M 13435), (Achlya bisexualis Coker, M32705), (Anemonia sulcata Pennant, X53498), (Apusomonas proboscidea Alexeieff, L37037), (Artemia salina Leach, X01723), (Aureobasidium pullulans (De Bary) Arnaud, M55639), (Cafeteria roenbergensis Fenchel et Patterson, L27633), (Cercomonas sp. 1 Dujardin., U42448), (Cercomonas sp. 2 Dujardin, U42449),
(Cercomonas sp. 3 Dujardin, U42450), (Cercomonas sp. 4 Dujardin, U42451), (Chlamydomonas reinhardtii Dangeard, M32703), (Chondrus crispus Stackhouse, Z14140), (Chlorarachnion reptans Geitler, nuclear, U03477), (Chlorarachnion sp. 1, nuclear, U 02075), (Cryothecomonas aestivalis strain 2, Drebes, Kühn et Schnepf, AF290541), (Cryothecomonas longipes, Schnepf et Kühn 2000, AF290540), (Cryothecomonas aestivalis strain 1, AF290539), (Cyanophora paradoxa Korschikov, X68483), (Emiliania huxleyi (Lohman) Hay et Mohler, M87327), (Euglypha rotunda Wailes, X77692), (Friedmannia israelensis Chantanachat et Bold, M62995), (Fucus distichus Linnaeus, M97959), (Glaucocystis nostochinearum, Itzigsohn, X70803), (Glaucosphaera vacuolata, Korshikov, X81903), (Hanusia phi Hill et Wetherbee = Cryptomonas phi, nuclear, X57162), (Hanusia phi Hill et Wetherbee = Cryptomonas phi, nucleomorph, X57008), (Hartmannella vermiformis Page, M95168), (Heteromita globosa Dujardin, U42447), (Klebsormidium flaccidum (Kütz) Silva, Mattox et Blackwell, M95613), (Lagenidium giganteum Couch, M54939), (Ochromonas danica Pringsheim, M32704), (Oxytricha nova D. Prescott, M14601), (Paulinella chromatophora Lauterborn, X81811), (Paramecium tetraurelia, Sonneborn, X03772), (Phaeocystis globosa Scherffel, X77476), (Phytophthora megasperma, Drechsler, M54938), (Plasmodiophora brassicae Woronin, U18981), (Prorocentrum micans Ehrenberg, M 14649), (Rhodomonas salina (Wislouch) Hill et Wetherbee $=$ Pyrenomonas salina (Wislouch) Santore, nuclear, X554276), (Rhodomonas salina (Wislouch) Hill et Wetherbee $=$ Pyrenomonas salina (Wislouch) Santore, nucleomorph, X55032), (Skeletonema costatum (Greville) Cleve, X85395), (Synura spinosa Korschikov, M 87336), (Thaumatomonas sp. De Saedeler, M 42446), (Trypanosoma theileri Laveran, AJ 009164), (Trypanosoma vespertilionis Battaglia, AJ 009166), (Zamia pumila Linnaeus, M20017), (Zea mays Linnaeus, K02202).

\section{References}

Beam CA, Preparata R-M, Himes M, Nanney DL (1993) Ribosomal RNA sequencing of members of the Crypthecodinium cohnii (Dinophyceae) species complex: comparison with soluble enzyme studies. J Euk Microbiol 40: 660-667

Bhattacharya D, Helmchen T, Melkonian M (1995) Molecular evolutionary analyses of nuclear-encoded small subunit ribosomal RNA identify an independent rhizopod lineage containing the Euglyphina and the Chlorarachniophyta. J Euk Microbiol 42: 65-69 
Castlebury LA, Domier, LL (1998) Small subunit ribosomal RNA gene phylogeny of Plasmodiophora brassicae. Mycologia 90: 102-107

Cavalier-Smith T (1993) The protozoan phylum Opalozoa. J Euk Microbiol 40: 609-615

Cavalier-Smith T (1996/1997) Amoeboflagellates and mitochrondrial cristae in eukaryote evolution: Megasystematics of the new protozoan subkingdoms Eozoa and Neozoa. Arch Protistenkd 147: 237-258

Cavalier-Smith T (1998a) A revised six-kingdom system of life. Biol Rev 73: 203-266

Cavalier-Smith T (1998b) Neomonada and the Origin of Animals and Fungi. In Coombs GH, Vickerman $K$, Sleigh MA, Warren A (eds) Evolutionary relationships among Protozoa. Kluwer, London pp 375-407

Cavalier-Smith T (2000) Flagellate Megaevolution: the Basis for Eukaryote Diversification. In Green J R and Leadbeater BSC (eds) The Flagellates. Taylor and Francis, London, pp 361-390

Cavalier-Smith T, Chao EE (1995) The opalozoan Apusomonas is related to the common ancestor of animals, fungi, and choanoflagellates. Proc R Soc Lond B 261: $1-6$

Cavalier-Smith T, Chao EE (1996/97) Sarcomonad ribosomal RNA sequences, rhizopod phylogeny, and the origin of euglyphid amoebae. Arch Protistenkd 147: 227-236

Doyle J J , Doyle J L (1990) Isolation of plant DNA from fresh tissue. Focus 12: 13-15

Drebes G, Kühn SF, Gmelch A, Schnepf E (1996) Cryothecomonas aestivalis sp. nov., a colourless nanoflagellate feeding on the marine centric diatom Guinardia delicatula (Cleve) Hasle. Helgol Wiss Meeresunters 50: 497-515

Felsenstein J (1993) PHYLIP manual, version 3.5. Distributed by the author, Department of Genetics, Univ. Washington, Seattle

Fitch WM, Margoliash E (1967) Construction of phylogenetic trees: a method based on mutation distances as estimated from cytochrome $c$ sequences is of general applicability. Science 155: 279-284

Guillard RRL, Ryther J H (1962) Studies on marine phytoplankton diatoms. 1. Cyclotella nana Hustedt and Detonula confervacea (Cleve) Gran. Can J Microbiol 8: 229-239

Ikävalko J, Thomsen HA (1997) The Baltic Sea biota (March 1994): A study of the protistan community. Europ J Protistol 33: 229-243

Karpov SA (1997) Cercomonads and their relationship to the myxomycetes. Arch Protistenkd 148: 297-307

Karpov SA, Fogin SI (1995) The structural diversity of the flagellar transition zone in heterotrophic flagellates and other protists. Cytology 37: 1038-1052
Karpov SA, Zhukov BF (1986) Ultrastructure and taxonomic position of Apusomonas proboscidea Alexeieff. Arch Protistenkd 131: 13-26

Kimura M (1980) A simple method for estimating evolutionary rates of base substitution through comparative studies of sequence evolution. J Mol Evol 16: 111-120

Knowlton N (1993) Sibling species in the sea. Annu Rev Ecol Sys 24: 189-216

Kühn S, Drebes G, Schnepf E (1996) Five species of the nanoflagellate Pirsonia in the German Bight, North Sea, feeding on planktic diatoms. Helgoländer Meeresunters 50: 205-222

Lange M (1997) Phylogeny and Taxonomy of the genus Phaeocystis (Prymnesiophyceae). Ph.D dissertation. University of B remen, B remen

Larsen L, Olsen GJ, Maidak BL, McCaughey MJ, Overbeek R, Macke R, Mash TL, Woese, CR (1993) The ribosomal database. Nucleic Acids Res 21 (suppl): 3021-3023

MacDonald CM, Darbyshire J F, Ogden, C C (1977) The morphology of a common soil flagellate, Heteromita globosa Stein (Mastigophorea: Protozoa). Bull Br Mus nat Hist (Zool.) 31: 255-264

Medlin LK, Lange M, Baumann MEM (1994) Genetic differentiation among three colony-forming species of Phaeocystis: further evidence for the phylogeny of the Prymnesiophyta. Phycologia 33: 199-212

Medlin LK, Elwood HJ, Stickel S, Sogin ML (1988) The characterization of enzymatically amplified eukaryotic 16S-like rRNA-coding regions. Gene 71: 491-499

Medlin LK, Elwood HJ, Stickel S, Sogin ML (1991) Morphological and genetic variation within the diatom Skeletonema costatum (Bacillariophyta): evidence for a new species Skeletonema pseudocostatum. J Phycol 27: $514-524$

Medlin LK, Lange M, Barker GLA, Hayes, PK (1995) Can molecular techniques change our ideas about the species concept? Nato ASI Series 38: 133-152

Mignot J -P, Brugerolle G (1975) Étude ultrastructurale de Cercomonas dujardin (=Cercobodo krassilstchick), protiste flagellé. Protistologica 11: 547-554

Mylnikov AP (1986) Ultrastructure of a colourless amoeboid flagellate, Cercomonas sp. Arch Protistenkd 131: $239-247$

Olsen GJ, Matsuda H, Hagstrom R, Overbeek R (1994) Fast DNAml: a tool for construction of phylogenetic trees of DNA sequences using maximum likelihood. CABIOS 10: 41-48

Patterson DJ , Larsen J (1991) The Biology of Free-living Heterotrophic Flagellates. Systematics Association Special Volume No.45. Clarendon Press, Oxford

Patterson DJ , Zölffel M (1991) Heterotrophic Flagellates of Uncertain Taxonomic Position. In Patterson DJ , Larsen J (eds) The Biology of Free-living Heterotrophic 
Flagellates. Systematics Association Special Volume No. 45. Clarendon Press, Oxford, pp 427-475

Preparata R-M, Beam CA, Himes M, Nanney DL, Meyer EB, Simon EM (1992) Crypthecodinium and Tetrahymena: an exercise in comparative evolution. J Mol Evol 32: 209-218

Robertson M (1928) Notes on Heteromita (Protozoa, Flagellata). Parasitology 20: 10-14

Sambrook J, Fritch EF, Maniatis T (1989) Molecular Cloning: a Laboratory Manual. 2nd ed. Cold Spring Harbor Laboratory Press, New Y ork, 3 vols

Schlegel M (1991) Protist evolution and phylogeny as discerned from small subunit ribosomal RNAs. Europ J Protistol 27: 207-219

Schnepf E, Kühn S (2000) Food uptake and fine structure of Cryothecomonas longipes sp. nov., a marine nanoflagellate incertae sedis feeding phagotrophically on large diatoms. Helgol Mar Res 54: 18-32

Schuster FL, Pollak A (1978) Ultrastructure of Cercomonas sp., a free-living ameboid flagellate. Arch P rotistenkd 120: 206-212

Shirkina NJ (1987) Morphology and life cycle of Thaumatomonas lauterbornii de Saedeleer (Mastigophora Diesing). Trudy/Akademija Nayuk SSSR, Institut Biologii Vrutrernich Vod=Transactions/Institute of Biology of Inland Waters 54: 87-107

Sogin ML, Gunderson J H, Elwood HJ, Alonso RA, Peattie DA (1989) Phylogenetic meaning of the kingdom concept: an unusual ribosomal RNA from Giardia lamblia. Science 243: 75-77
Sogin ML, Ingold A, Karlok M, Nielsen $H$, Engberg J (1986) Phylogenetic evidence for the acquisition of ribosomal RNA introns subsequent to the divergence of some of the major Tetrahymena groups. EMBO J 5: 3625-3630

Swofford DL (1993) PAUP: Phylogenetic analysis using parsimony. Version 3.1.1. Illinois Natural History Survey, Champaigne IL

Tillmann U, Hesse KJ , Tillmann A (1999) Large-scale parasitic infection of diatoms in the Northfrisian Wadden Sea.J Sea Research 42: 255-261

Thomsen HA, Buck KR, Bolt PA, Garrison DL (1991) Fine structure and biology of Cryothecomonas gen. nov. (Protista incertae sedis) from the ice biota. Can J Zool 69: 1048-1070

Van de Peer Y, De Wachter R (1997) Evolutionary relationships among the eukaryotic crown taxa taking into account site-to-site rate variation in 18S rRNA. J Mol Evol 45: 619-630

Vaulot D, Birrien J -L, Marie D, Casotti R Veldhuis M, Kraay G, Chrétiennot-Dinet M-J (1994) Morphology, ploidy, pigment composition, and genome size of cultured strains of Phaeocystis (Prymnesiophyceae)J Phycol 30: 1022-1035

Ward E, Adams MJ (1998) Analysis of ribosomal DNA sequences of Polymyxa species and related fungi and the development of genus- and species-specific PCR primers. Mycol Res 102: 965-974

Woese CR (1987) Bacterial evolution. Microbiol Rev 51: 221-271 